\title{
The Impact of Human Resources Development on Small and Medium Enterprises (SMEs) Performance: The Case of Kosovo
}

\author{
Zeqir Voca ${ }^{1} \&$ Ymer Havolli \\ ${ }^{1}$ Tax Administration of Kosovo, Kosovo \\ ${ }^{2}$ Department of Management, Faculty of Economy, University of Prishtina, Kosovo \\ Correspondence: Zeqir Voca, Tax Administration of Kosovo, Kosovo. E-mail: zeqirvoca@hotmail.com, \\ ymer.havolli@uni-pr.edu
}

Received: May 21, 2019; Accepted: June 4, 2019; Published: June 10, 2019

\begin{abstract}
The purpose of this paper is to study the impact of the Human Resources Development (HRD) on the performance of small and medium enterprises (SMEs) in Kosovo. There is a large volume of research that support the positive relationship between HRD and the organizational performance. Most of such research was conducted in the developed countries and to a lesser extent in the developing countries (countries in transit). Through this study we confirmed the impact of the investments in various forms of HRD in the performance of the SMEs in Kosovo. This study provides empirical data that support the impact of training and development, career development and motivation of employees on organizational performance, but the results of this study do not support the impact of the education of entrepreneurs on the organizational performance.
\end{abstract}

Keywords: human resource, human resource development, organizational performance, small and medium enterprises

\section{Introduction}

The changes in the technological, economic, social and political field have also an impact on the field of broadening the knowledge as a very important factor in the creation of new organizational values. In this respect, the only resource of the organization that has knowledge is the human and this knowledge should be constantly updated in order to keep up with the competition and to meet the objectives of the organization. In today's competitive and dynamic environment, HRD helps organizations to be more innovative, successful in the market, competitive, improve and adapt itself with the changing environment (Mittal, 2013). HRD is an important component and one of the fundamental objectives in the successful management of HR, because the value of employees in the enterprise in the economy of knowledge is closely related to their specific skills, abilities and knowledge (Garavan, 2007). Whereas these values can be enhanced only through the continuous development of employees. There is a large volume of research in the field of employee development that show that the investments of enterprises in various forms of HRD, such as training and development, continuous professional education etc. have a positive effect on the organizational performance (Kraiger et al., 2004). By investing in HRD, the organizations enhance the value of these resources by acquiring employees with new knowledge, skills and abilities the organization is in need of, thus fulfilling its strategy and objectives.

In the new economy, known as economy of knowledge, the business environment is variable and dynamic and in such environment there are complex interactions between human resources and other material resources (Oginni \& Adesanya, 2013). This dynamic environment is characterized by phenomena such as globalization, digitalization, change in needs and demands of consumers, as well as the growing competition in the market of almost all products and services (Çalişkan, 2010). From these environmental factors, the impact of globalization of work may be one of the most important ones (Bud \& Hanun, 2016). On one hand, globalization has had an impact on the expansion and gradual growth of markets and reduction of barriers to access to these markets, but on the other hand the globalization has had an impact on the continuous growth of competition among businesses (Shoraj \& Llaci, 2015). In such conditions of globalization, the value of HR has continuously increased.

With the change of environment also the nature and mode of work in organizations changes, therefore the employees are required to develop new skills, abilities and knowledge which are necessary for the success of organizations (Grossman \& Salas, 2011). According to Torraco (2005) the implications of HRD for the adjustment of organizations to new working environments provide arguments for the importance of the development of labor 
force through various forms by way of which the continuous education is ensured. Learning and development of skills of employees through trainings, development of reeducation are very important because the trained labor force the organization will more easily adjust to the new dynamic environments and unpredicted circumstances.

The new technology presents an indispensable need for organizations to develop their employees. The application of new technology requires new working methods and new skills for using such technology. According to Torraco \& Swanson (1995), in the evolution of HRD as an important component in the execution of business strategy, two factors have had an impact: (1) The even increasing importance of information technology for the continuous success of business, and (2) the increase in importance of specific knowledge of human resources in achieving competitive advantages in the market ensured by the specific knowledge and skills of the labor force. The information technology and specific knowledge of employee are interrelated in the manner that in order to ensure competitive advantages in the market it is necessary to develop the labor force through various forms, such as training and development, seminars, workshops, professional education, etc., so that this labor force is able and competent in the performance of works and duties as required.

The activities and practices of HRD can play an important role in adapting the employees to the new working methods fostered by the technological changes. According to a large number of authors, the activities of enterprises for successfully coping with these technological changes are realized through programs of reeducation, training and development, career management and multiple skills, through the improvement of the performance of HR ( Torraco, 2005; DeCenzo et al., 2010; Armstrong, 2012).

HRD is important not only for organizations but also for the economic development of countries and global competition. The studies and research in HRD focused on global and regional level have proven that the growth and development of developed and developing countries is a result of continuous investments in HRD (Kumari \& Mishra, 2009).

A large number of authors through their research have provided arguments about the great importance of SMEs in the economic development of the countries. SMEs play an important role especially in the generation of new jobs, increase in Gross Domestic Product (GDP), development of entrepreneurship, increase in competition, etc. (Krasniqi, 2007; Hyz, 2011; Karadag, 2016; Abbasi et al., 2017). Considering this great importance of SMEs in the economic development, they should invest in various forms of practices of HRD, regardless of the sector they operate in, their size or location they exercise their activity. In this manner, SMEs will be competitive and successful in the market.

\subsection{Statement of the Problem}

A large number of enterprises in Kosovo are SMEs, approximately 99,80\% (Tax Administration of Kosovo - TAK, 2018). The performance of SMEs of Kosovo is not satisfactory. This is confirmed by a lot of research conducted in relation to the performance of Kosovo enterprises. Hence, according to the research of BSC Kosovo (Business Support Centre Kosovo, 2013), 38.41\% of enterprises included in the research have stated that that the sales in 2012 are lower than those in the previous year, whereas $41.33 \%$ stated that the profit in 2012 compared to that of the previous year is lower. Similarly, after the research conducted by Riinvest (2017), 27.00\% of enterprise included in the research stated that they have decrease in sales compared to previous year. Two other indicators: unregistered business and passive businesses show the poor performance of these enterprises. The number of unregistered businesses in the period 1999-2016 is 8.9\% of those registered (Kosovo Business Registration Agency - KBRA, 2017), whereas the number of passive businesses is much higher, $31.91 \%$ (TAK 2019). This is a signal as to what needs to be changed in the management of these enterprises. Since in the knowledge-based economy, the human resources and their potential are the most important source of organizations and the main factor that contributes to the fulfillment of enterprise objectives, Kosovo SMEs should create programs for the development of these sources in different manners and this department should be continuous, in line with the needs of the enterprise and the market needs.

\section{Literature Review}

In theoretical aspect, the concept of HRD as a term started to be used from the second half of XX century and many authors dealt with this area, who give various concepts and definitions about HRD. The large number of authors define $\mathrm{HRD}$ as a process of training, development, and continuous education of human resources, in order to increase both individual and team and organizational performance. Hence, Swanson (1995) defined HRD "as a process of the development of human knowledge through training and development and development of organization for the purpose of increasing the performance". Whereas according to Armstrong (2012), development is "the growth or realization of a person's ability and potential through the provision of learning and educational experiences". 
In the new economy, knowledge-based economy, the training and development of employees in organization has become a need and important and necessary practice in the modern management of HR, in order to improve the performance (Kraja, 2015). Through activities and practices of HRD, employees acquire specific knowledge and new skills and abilities. However, this investment in HRD should be in line with the needs of business and market, otherwise the invested funds will only be a cost without any effect on the business (Torraco \& Swanson 1995). HRD helps the organizations to achieve competitive advantage by creating capable and knowledgeable human resources which cannot be imitated by the competitors and are irreplaceable (Hatch \& Dyer 2004).

HRD is an integral part of the human resources management (HRM). This development is important for the organizations because it helps them to reach their objectives and strategies. HRD has a positive impact on various forms of performance (Çalişkan, 2010; Hameed \& Waheed 2011; Okoye \& Ezejiofor 2013; Budd \& Hannum 2016; Sandamali et al., 2018). According to Mabey (2008), strategic approach to the development of managers distinguishes the high performance companies from their competitors, regardless of the size of the enterprise, sector or national context.

Training is an important component in HRD, and that is why a large number of empirical studies address various training topics, starting from all forms of trainings for employees, training of managers, training of team, crosscultural training, etc. (Arthur, et al., 2003; Keith \& Frese, 2008; Morris \& Robie, 2001; Powell \& Yalcin, 2010). These studies provide arguments that when a training is well organized, either in-house or outside work and is based on the science of learning and training, then the training will yield positive results. The investment in trainings is important for the enterprise since this investment will result in a higher employee's performance (Shaukat et al., 2015); in the increase in productivity and salaries (Barron et al., 1999); a suitable work environment and satisfied consumers (Wrigt et al. 2003); and that the training and development activities enable the organizations to adjust more easily, to be competitive in the market and to differ from competitors, to be innovative, to be secure, to improve production and service, and this way to meet their goals (Salas et al., 2012); higher productivity and wages (Gagnon \& Smith, 2013).

\subsection{Theories of $H R D$}

There is a number of scientific theories that support the investment of organizations in HRD. In this paper we will discuss two main theories: human capital theory and resource-based theory.

\subsubsection{Human Capital Theory}

Human capital theory has had a huge impact on different kinds of disciplines from economics to education and sociology (Tan, 2014). This theory is related to the way in which people employed in the organization - HR, contribute with their knowledge, skills and abilities to increasing the opportunities and organizational performance (Armstrong \& Taylor, 2014). According to Kumar (2006), the human capital is related to the skills and abilities of HR in organizations, which are acquired through education, training and work experience, by helping the organization in the fulfillment of its objectives. Thus, human capital importance is growing continuously for the organizations in the modern knowledge society (Lechthaler, 2011).

One of the first researches related to the human capital theory and return in investments is that of Schultz (1961). According to him the largest part of operating expenses of an enterprise consists in the investment in human capital. The expenses of enterprise in education, training, health and internal movements of employees are investments in human capital, and that such investment has a positive effect on the increase in actual income of employees. Whereas the greatest contribution to the development of human capital theory was given by Becker (1962). Becker considers the education and training as an important investment in the human capital. Through empirical research he came to the conclusion that many employees in organizations increase the work productivity through education and trainings by learning new skills and improving the old ones through their work experience. Therefore, the human capital management in organizations has become an important and indispensable factor in maintaining and improving the organizational performance (Bowen \& Ostroff, 2004). One of the most important activities of the organization for the good management of human capital is the development of such capital. By investing in the growth of human capital through investments in the health of employees, training and education it increases the work productivity of employee, their performance and the performance of the organization. By developing the human capital the enterprise will be more competitive in the marked and it will be more difficult for competition to imitate it (Echdar, 2013).

\subsubsection{Resource-Based Theory}

The resource-based view (RBV) initially derives from the studies of Edith Penrose (1959). RBV gives an answer to the question as to why some enterprises are more successful than other enterprises, by generating continuous 
profits. (Chisholm \& Nielsen, 2009). RBV is based on the fact that the differences between enterprises from HR aspect, organizational and physical aspect, result in heterogeneity in their production potential. Considering this, the long term competition of an enterprise, participation in the market and its performance depends on the resources which are not only different from those of its competitors, but are also sustainable and difficult to be imitated or replaced (Mahoney \& Pandian, 1992; Boxall 1996; Arend \& Levesque, 2010).

Human resources are one of the most important resources through which the enterprises create a sustainable competitive advantage. Hence, Boxall (1996) suggested that RBV of enterprise provides an important foundation, to confirm that HR are the most important resource of competitive advantages in the market. Whereas, according to authors Lado \& Wilson (1994), the good HR systems provide a potential for a sustainable competitive advantage, through HRD, by developing competencies which are specific for enterprises and which generate tacit organizational knowledge.

\section{Methodology}

In this research paper we have used two research methods to analyze HRD factors and their impact on organizational performance. Firstly, we have applied secondary method while using published data from different scientific journals, academic books published recently, that have to do with HRD issue, and also data published from domestic and international institutions like: Institute for Development Research - Riinvest, Business Support Centre of Kosovo (BSC Kosovo), Kosovo Business Registration Agency (KBRA), Tax Administration of Kosovo (TAK) etc. Secondly, we have used the quantitative method for collecting primary data. The instrument for the collection of data was the questionnaire which contained 67 questions. The manner of implementation was the direct contact with the respondents (face to face). The data processing was done by SPSS.

\subsection{The Sample}

For the needs of this paper we have planned and used a sample of 386 SMEs in Kosovo. In the selection of the sample the businesses were divided by three sectors: trade (53.10\%), production $(25.13 \%)$, and services $(21.77 \%)$, and by size of businesses: micro enterprises (68.95\%), small enterprises $(24.87 \%)$, and medium enterprises $(5.18 \%)$. The selection of SMEs for research - the sample, was done according to the random method and was extended to all large cities of Kosovo. We have tried to make the selected sample as representative as possible.

Table 1. Selection of sample

\begin{tabular}{lllll}
\hline Size/Sector & Trade & Production & Services & Total \\
\hline Micro enterprise & 143 & 67 & 60 & $\mathbf{2 7 0}$ \\
Small enterprise & $(37.05 \%)$ & $(17.36 \%)$ & $(15.54 \%)$ & $\mathbf{( 6 9 . 9 5 \% )}$ \\
& 51 & 25 & 20 & $\mathbf{9 6}$ \\
Medium enterprise & $(13.21 \%)$ & $(6.48 \%)$ & $(5.18 \%)$ & $\mathbf{( 2 4 . 8 7 \% )}$ \\
& 11 & 5 & 4 & $\mathbf{2 0}$ \\
Total & $(2.85 \%)$ & $(1.29 \%)$ & $(1.04 \%)$ & $\mathbf{( 5 . 1 8 \% )}$ \\
& $\mathbf{2 0 5}$ & $\mathbf{9 7}$ & $\mathbf{8 4}$ & $\mathbf{3 8 6}$ \\
& $\mathbf{( 5 3 . 1 0 \% )}$ & $\mathbf{( 2 5 . 1 3 \% )}$ & $\mathbf{( 2 1 . 7 7 \% )}$ & $\mathbf{( 1 0 0 \% )}$ \\
\hline
\end{tabular}

Source: Survey with 386 SMEs in Kosovo

\subsection{Hypotheses}

In order to examine how HRD affects the performance of SMEs, the following hypotheses will be tested:

H1: Education of Entrepreneurs has a positive relationship with organizational performance

H2: Training and Development have a positive relationship with organizational performance

H3: Career development has a positive relationship with organizational performance

H4: Motivation of employees has a positive relationship with organizational performance

\subsection{Model and Empirical Findings}

In the study, the multiple linear regression was used to verify the hypotheses. The purpose of using the regression model is to establish the relationship between the dependent variable and the independent ones. As the dependent variable in this study was used the organizational performance whereas independent variables are education of entrepreneurs, training and development, career development and motivation of employees. 
Performance $=\beta 0+\beta 1$ Education of entrepreneurs $+\beta 2$ Training and Development $+\beta 3$ Career development + $\beta 4$ Motivation of employees

Table 2. Model Summary

Model Summary ${ }^{\mathrm{b}}$

\begin{tabular}{|c|c|c|c|c|c|c|c|c|c|c|}
\hline \multirow[t]{2}{*}{ Model } & \multirow[t]{2}{*}{$\mathrm{R}$} & \multirow{2}{*}{$\begin{array}{l}\mathrm{R} \\
\text { square }\end{array}$} & \multirow{2}{*}{$\begin{array}{l}\text { Adjusted } \\
\text { R square }\end{array}$} & \multirow{2}{*}{$\begin{array}{l}\text { Std.Error } \\
\text { of the } \\
\text { Estimate }\end{array}$} & \multicolumn{5}{|c|}{ Change statistics } & \multirow{2}{*}{$\begin{array}{l}\text { Durbin- } \\
\text { Watson }\end{array}$} \\
\hline & & & & & $\begin{array}{l}\mathrm{R} \\
\text { square } \\
\text { change }\end{array}$ & $\begin{array}{l}\text { F } \\
\text { change }\end{array}$ & df1 & $\mathrm{df} 2$ & $\begin{array}{l}\text { Sig. F } \\
\text { change }\end{array}$ & \\
\hline 1 & $.526^{\mathrm{a}}$ & .277 & .269 & 336.292 & .277 & 36.378 & 4 & 380 & .000 & 2.040 \\
\hline
\end{tabular}

a. Predictors: (Constant), education of entrepreneurs, training \& development, career development, motivation of employees

b. Dependent variable: organizational performance

Source: Author's calculation

The table of model summary is a table that shows important values of $\mathrm{R}, \mathrm{R}^{2}$, adjusted $\mathrm{R}^{2}$, and the standard error of the estimate, etc. The value of $R=0.526$, whereas the coefficient of determinants $R^{2}=0.277$ which shows what percentage of the dependent variable is explained by the independent variables. In our example, $27.7 \%$ of the change in the dependent variable is explained by the independent variables (education of entrepreneurs, training and development, career development and motivation of employees). An important test is Durbin-Watson test which shows if there is an autocorrelation in our model. The values of Durbin-Watson test is 2.040, within the permitted norm, and therefore there is no autocorrelation.

Table 3. ANOVA

ANOVA $^{\text {a }}$

\begin{tabular}{lllllll}
\hline Model & & Sum of squares & Df & Means square & F & Sig. \\
\hline 1 & Regression & 16456191.157 & 4 & 4114047.789 & 36.378 & $.000^{\text {b }}$ \\
& Residual & 42975083.260 & 380 & 113092.324 & & \\
& Total & 59431274.417 & 384 & & & \\
\hline
\end{tabular}

a. Dependent Variable: organizational performance

b. Predictors: (Constant), education of entrepreneurs, training \& development, career development, motivation of employees

Source: Author's calculation

ANOVA table is used to test the significance of the model as a whole. The value in this table of coefficient $\mathrm{F}=$ 36.378 , shows that our model is significant at any level as a whole $\mathrm{p}=0.000<0.05$.

Table 4. Coefficients

Coefficients $^{\mathrm{a}}$

\begin{tabular}{|c|c|c|c|c|c|c|c|}
\hline \multirow[t]{2}{*}{ Model } & \multicolumn{2}{|c|}{ Unstandardized Coefficients } & \multirow{2}{*}{$\begin{array}{l}\text { Standardized } \\
\text { Coefficients } \\
\text { Beta }\end{array}$} & \multirow[t]{2}{*}{$\mathrm{t}$} & \multirow[t]{2}{*}{ Sig. } & \multicolumn{2}{|c|}{ Collinearity Statistics } \\
\hline & $\underline{B}$ & Std. Error & & & & Tolerance & VIF \\
\hline (Constant) & 46.118 & 75.564 & & .610 & .542 & & \\
\hline Education of entrepreneurs & -38.643 & 25.837 & -.066 & -1.496 & .136 & .987 & 1.013 \\
\hline Training and Development & .025 & .002 & .468 & 10.239 & .000 & .913 & 1.096 \\
\hline Career development & 36.497 & 16.343 & .102 & 2.233 & .026 & .907 & 1.102 \\
\hline Motivation of employees & 25.656 & 10.386 & .108 & 2.470 & .014 & .988 & 1.012 \\
\hline
\end{tabular}

a. Dependent Variable: Organizational performance

Source: Author's calculation 
The table of coefficients shows the values of parameters of the model results, and the values of coefficient $t$. The statistical values of the parameters can be seen for each variable separately as to how important they are (at the level of significant $5 \%$ ). While value $\mathrm{F}$ was used to test the importance of the model as a whole, the $\mathrm{t}$ value is used to test the importance of the variables separately.

Regarding the independent variable, the education of entrepreneurs, value $t=-1.496$, hence $<1.95$ and $p$-value is $=0.136$, hence $>0.05$. Therefore, we conclude that Hypothesis $\mathrm{H} 1$ is not accepted. The education of entrepreneurs does not have an impact on the performance of enterprise. The results are similar to some previous studies, based on which the entrepreneurship success is less related to the formal education and more positively related to the entrepreneurship experience (Dencker et al., 2009; Martin et al., 2013; Toft-Kehler et al., 2014).

Regarding the independent variable, training and development, the $t$ value $=10.239$, hence $>1.95$, and $p$-value is 0.000 , hence $<0.05$ which means that hypothesis $\mathrm{H} 2$ is accepted. The investments of the enterprise in training and development of HR have a positive effect and impact on the performance of enterprise. The table of coefficients shows that the greatest value of Beta coefficient is with training and development $(0.468)$ and this explains that training and development compared to other variables has an important and significant impact on the organizational performance. Therefore, any growth and investment in training and development will have an impact on this performance. These findings are in line with the study of Kalleberg \& Moody (1994), who provide arguments that training has a positive impact on various aspects of the performance of enterprise: profit of enterprise, product quality, product development, market share, and sale increase. The results are also in line with the findings of many other authors who in their studies provided arguments that training has an impact on the increase in organizational performance (Delaney \& Huselid, 1996); on higher employee's performance (Shaukat et al., 2015). Gamage (2007) argues that there is a positive relationship between the practices of HRD and the performance of Japanese SMEs. In addition, Katou (2008), argued that SME has a positive relationship with the performance. Whereas Sandamali et al. (2018), argued about the significant impact of training and development on the performance of employees.

Regarding the independent variable, career development, $t$ value $=2.233$, hence $>1.95$ and $p$-values $=0.026$, hence $<0.05$, therefore we can say that the career development of human resources has a positive impact on the performance of enterprise and hypothesis $\mathrm{H} 3$ is accepted. But this impact compared to the training and development is lower (Beta $=0.102)$. The results are similar to some previous studies, based on which the career development has a positive impact on the performance (Mohamad \& Yahya, 2017; Dialoke \& Nkechi, 2017; Suyanto et al., 2018). But these findings are not in compliance with some other studies which do not argue the positive impact of career development on the performance (Noe, 1996; Mark \& Nzulwa, 2018).

The fourth independent variable, motivation of employees has a positive impact on the performance since the value $\mathrm{t}=2.470>1.95$ and $\mathrm{p}$-value is $=0.014$ which is $<0.05$, therefore $\mathrm{H} 4$ is accepted. The employees motivated at work have a large impact on the performance of enterprise. These results are also similar to some previous studies, based on which the motivation of employees has a positive impact on the performance of employees and organizational performance (Bao \& Nizam, 2015; Said et al., 2015; Onanda, 2015).

Based on the results from the model, we obtain the regression equation:

$$
\mathrm{Y}=46.118-38.643 \mathrm{X} 1+0.025 \mathrm{X} 2+.36 .497 \mathrm{X} 3+25.656 \mathrm{X} 4
$$

\section{Conclusion and Discussion}

The theoretical contribution of this study consists in the creation and testing of the regression model. Through this model we tested the relationship between the education of entrepreneurs, training and development, career development and motivation of employees and the organizational performance. The results of the model based on the data of SME sector in Kosovo show that the formal education of entrepreneurs does not have an impact on the performance of enterprise, therefore we have many successful enterprises in Kosovo which are managed by the entrepreneurs with low level of education and vice versa, we have entrepreneurs with high level of education who manage enterprises with low performance, due to the fact that the programs of education system in Kosovo do not correspond to the needs of these businesses. The empirical analysis of this study show that training and development, career development and motivation of employees result with a higher performance of enterprises. Based on the findings of this model, the biggest importance and impact on the performance of Kosovo enterprises have the training and development. The model also shows that motivation at work and employees and career development have a positive impact on the performance of enterprises but this impact is less important than training and development. 


\section{Practical Implications and Recommendations}

HRD is needed for any organization that wants to be successful in a knowledge-based economy. Kosovo's SMEs can grow, develop, and succeed in the changing and dynamic environment only through increasing the knowledge, skills and competencies of human resources. Therefore the focus of these enterprises should be on the bigger investment in training and development. This way the Kosovo enterprises will better respond to competition and to the demands of consumers which continuously change. The funds invested in training and development should not be considered as cost of business only, but as an investment in the more secure future of enterprise. This way enterprises will have HR with skills and abilities that will contribute to the fulfillment of these goals and strategies of the enterprises.

\section{References}

Abbasi, W. A., Wang, Z., \& Abbasi, D. A. (2017). Potential Sources of Financing for Small and Medium Enterprises (SMEs) and Role of Government in Supporting SMEs. Journal of Small Business and Entrepreneurship Development, 5(2), 39-47. https://doi.org/10.15640/jsbed.v5n2a4

Arend, R. J., \& Lévesque, M. (2010). Is the Resource-Based View a Practical Organizational Theory? Organization Science, 21(4), 913-930. https://doi.org/10.1287/orsc.1090.0484

Armstrong, M. (2012). Armstrong'Handbook of Human Resource Menagement Practice. KoganPage, page, 274.

Armstrong, M., \& Taylor S. (2014). Armstrong's handbook of human resource management practice 13th edition, page 7.

Arthur, W., Benett, W., Edens, P. S., \& Bell, S. T. (2003). Effectiveness of Training in Organizations: A MetaAnalysis of Design and Evaluation Features. Journal of Applied Psychology, Journal of Applied Psychology, 88(2), 234-245. http://doi.org/10.1037/0021-9010.88.2.234

Bao, C., \& Nizam, I. (2015). The impact of motivation on employee performance in the electronics industry in CHINA. International Journal of Accounting \& Business Management, 3(2), 29-45.

Barron, J. M., Berger, M. C., \& Black, D. A. (1999). Do Workers Pay for On-The-Job Training? The Journal of Human Resources, 34(2), 235-252. http://doi.org/10.2307/146344

Becker, B. (1962) Investment in Human Capital: A Theoretical Analysis. Journal of Political Economy, 70(5), Part 2, 9-49. http://dx.doi.org/10.1086/258724

Bowen, D. E., \& Ostroff, C. (2004): Understanding HRM-Firm Performance Linkages: The Role of the "Strength" of the HRM System. Academy of Management Review, 29(2), 203-221. http://doi.org/10.2307/20159029

Boxall, P. F. (1996). The strategic HRM debate and the resource-based view of the firm. Human Resource Management Journal, 6(3), 59-75.

BSC Kosovo. (2013). Entrepreneurship and Small Business Development in Kosovo in 2012. RESEARCH REPORT

Budd, M. L., \& Hannum, W. H. (2016). A New Vision for HRD to Improve Organizational Results: Educational Technology, 56(4), 21-25.

Çalişkan, E., N. (2010). The Impact of Strategic Human Resource Management on organizational performance. Journal of Naval Science and Engineering, 6(2), 100-116.

Chisholm, A. M., \& Nielsen, K. (2009). Social Capital and the Resource-Based View of the Firm. International Studies of Management \& Organization, 39(2), 7-32. https://doi.org/10.2753/IMO0020-8825390201

DeCenzo, A. D., Robbins, P. S., \& Verhults, S. L. (2010). Fundamentals of Human Resource Management 10th edition-Wiley page, 7.

Delaney, J. T., \& Huselid, M. A. (1996). The Impact of Human Resource Management Practices on Perceptions of Organizational Performance. Academy of Management Journal, 39(4), 949-969. https://doi.org/10.2307/256718

Dencker, J.C., Gruber, M., \& Shah, S. K. (2009). Pre-entry knowledge, learning, and the survival of new firms. Organization Science, 20(3), 516-537. https://doi.org/10.1287/orsc.1080.0387

Dialoke, I., \& Nkechi, P. A. J. (2017). Effects of career growth on employees performance: A study of nonacademic staff of michael okpara university of agriculture umudike abia state, Nigeria. Singaporean. Journal of Business economics, and management StudieS (SJBEM), 5(7), 8-18. 
Echdar, H. S. (2013). Effect of Internal and External Environment of Human Capital Development (Empirical Study on Manufacturing Company Gopublik in Indonesia), Journal of Business and Management, 11(3), $39-56$.

Gagnon, M. E., \& Smith, M. (2013). The Effects of a Training Levy on Training Characteristics and Outcomes: The Case of Quebec. Relations Industrielles / Industrial Relations, 68(1), 120-141.

Gamage, A. (2007). Impact of HRD Practices on Business Performance: An empirical analysis of manufacturing SMEsin Japan. $\quad$ pp. 85-109. Retrieved from https://learning.uonbi.ac.ke/courses/DHR503/document/impact_of_HRD_on_organisational_performance_ case.pdf

Garavan, Th. N. (2007). A strategic perspective on human resource development. Advances in Developing HumanResurces, 9(1), 11-30. https://doi.org/10.1177/1523422306294492

Grossman. R., \& Salas, E. (2011). The transfer of training: Wat really matters. Internacional Journal of Training and Development, 15(2), 103-120. https://doi.org/10.1111/j.1468-2419.2011.00373.x

Hameed, A., \& Waheed, A. (2011). Employee Development and Its Affect on Employee Performance A Conceptual Framework. International Journal of Business and Social Science, 2(1), 224-229.

Hatch, N. W., \& Dyer, J. H. (2004). Human Capital and Learning as a Source of Sustainable competitive Advantage. Strategic Management Journal, 25(12), 1155-1178. https://doi.org/10.1002/smj.421

Hyz, A. B. (2011). Small and Medium Enterprises (SMEs) in Greece - Barriers in Access to Banking Services. An Empirical Investigation, International Journal of Business and Social Science, 2(2), 161-165.

Institute for Development Research, Riinvest. (2017). The business climate in Kosovo from the perspective of SMEs (Albanian).

Kalleberg, A. L., \& Moody, J. W. (1994). Human Resource Management and Organizational Performance. American Behavioral Scientist, 37(7), 948-962. https://doi.org/10.1177/0002764294037007007

Karadag, H. (2016). The Role of SMEs and Entrepreneurship on Economic Growth in Emerging Economies within the Post-Crisis Era: An Analysis from Turkey. Journal of Small Business and Entrepreneurship Development, 4(1), 22-31. https://doi.org/10.15640/jsbed.v4n1a3

Katou, A. A. (2008). The Impact of Human Resource Development on Organisational Performance: Test of a Causal Model. Journal of Behavioral and Applied Management. Retrieved from https://www.researchgate.net/publication/242091942

KBRA (Kosovo Business Registration Agency). (2017). Report of Basic Performance Indicators for Business Registration in Kosovo for the Period: July-December 2016 (Albanian).

Keith, N., \& Frese, M. (2008). Effectiveness of error management training: A meta-analysis. Journal of Applied Psychology, 93(1), 59-69. https://doi.org/10.1037/0021-9010.93.1.59

Kraiger, K., McLinden, D., \& Casper, W. J. (2004). Collaborative Planning for Training Impact. Human Resource Management, 43(4), 337-351. https://doi.org/10.1002/hrm.20028

Kraja, G. (2015). Training, development and Performance (Case study of the Albanian Public Administration). Journal of Sociological Research, 6(1), 129-140. https://doi.org/10.5296/ jsr.v6i1.7905

Krasniqi, B. (2007). Barriers to entrepreneurship and SME growth in transition: the case of Kosova. Journal of Developmental Entrepreneurship, 12(1), 71-94. https://doi.org/10.1142/S1084946707000563

Kumar, Ch. Sh. (2006). Human Capital and Growth Empirics. The Journal of Developing Areas, 40(1), 153-179. https://doi.org/10.1353/jda.2007.0006

Kumari, P., \& Mishra, R. (2009). Implementing Human Resource Development as a tool for Effective Organization Change. SSRN (ssrn.com/abstract=1437844) https://doi.org/10.2139/ssrn.1437844

Lado, A. A., \& Wilson, M. C. (1994). Human resource systems and sustained competitive advantage: a competency based perspective. Academy of Management Review, 19(4), 699-727.

Lechthaler, W. (2011). Firm Training and Capital Taxation. Journal of Institutional and Theoretical Economics. Zeitschrift für diegesamte Staatswissenschaft, 167(2), 175-201.

Mabey, Ch. ( 2008). Management Development and Firm Performance in Germany, Norway, Spain and the UK. Journal of International Business Studies, 39(8), 1327-1342. https://doi.org/10.1057/palgrave.jibs.8400405 
Mahoney, J. T., \& Pandian, J. R. (1992). The resource-based view within the conversation of strategic management. Strategic Management Journal, 13(5), 363-380. https://doi.org/10.1002/smj.4250130505

Mark, L., \& Nzulwa, J. (2018). Effect of career development programs on employee performance in kenya. a case of national hospital insurance fund. International Journal of Social Sciences and Information Technology, $I V(\mathrm{~V}), 693-709$.

Martin, B. C., McNally, J. J., \& Kay, M. J. (2013). Examining the formation of human capital in entrepreneurship: A meta-analysis of entrepreneurship education outcomes. Journal of Firm Venturing, 28(2), 211-224. https://doi.org/10.1016/j.jbusvent.2012.03.002

Mittal Sh. (2013). HRD Climate in Public \& Private Sector Banks. Indian Journal of Industrial Relations, 49(1), 123-131.

Mohamad, M. H., \& Yahya, K. K. (2017). Perceived career development practice and performance of employees: an empirical study in the enforcement organization. Journal of Global Business and Social Entrepreneurship (GBSE), 1(4), 54-61.

Morris, M. A., \& Robie, Ch. (2001). A meta-analysis of the effects of cross-cultural training on expatriate performance and adjustment. International journal of training \& Development, 5(2), 112-125. https://doi.org/10.1111/1468-2419.00126

Noe, R., A. (1996). Is Career Management Related to Employee Development and Performance? Journal of Organizational Behavior, 17(2), 119-133.

Oginni, B. O., \& Adesanya, A. S. (2013). Business Environmental Factors: Implications on the Survival andGrowth of Business Organisations in the Manufacturing Sector of Lagos Metropolis. Business and Management Research, 2(3), 146-155 http://dx.doi.org/10.5430/bmr.v2n3p146

Okoye P.V.C \&. Ezejiofor, R., A. (2013). The- Effect of Human Resources Development on Organizational Productivity. International Journal of Academic Research in Business and Social Sciences, 3(10), 250-268 https://doi.org/10.6007/IJARBSS/v3-i10/295

Onanda, B. (2015). The effects of Motivation on Job performance, A case study of KCB Coast Region. International Journal of Scientific and Research Publications, 5(9), 1-13

Powell, K. S., \& Yalcin, S. (2010). Managerial training effectiveness: A meta-analysis 1952-2002. Personnel Review, 39(2), 227-241. https://doi.org/10.1108/00483481011017435

Said, N. Sh. M., Zaidee, A., Zahari, A. S. M., Ali, S., \& Salleh, S. M. (2015). Relationship between Employee Motivation and Job Performance: A Study at Universiti Teknologi MARA (Terengganu). Mediterranean Journal of Social Sciences, 6(4), 632-638. https://doi.org/10.5901/mjss.2015.v6n4s2p632

Salas, E., Tannenbaum, S. I., Kraiger, K., \& Smith-Jentsch, K. A. (2012). The Science of Training and Development in Organizations: What Matters in Practice. Psychological Science in the Public Interest, 13(2), 74-101. https://doi.org/10.1177/1529100612436661

Sandamali, J. G. M., Padmasiri, M. K. D. Mahalekamge, W. G. S., \& Mendis, M. V. S. (2018). The Relationship between Training and Development and Employee Performance of Executive Level Employees in Apparel Organizations. International Invention of Scientific Journal, 2(1), 12-17

Schultz, Th. W. (1961). Investment in Human Capital. The American Economic Association, 51(1), 1-17.

Shoraj, D., \& Llaci, Sh. (2015). Motivation and Its Impact on Organizational Effectiveness in Albanian Businesses. SAGE Open, pp. 1-8. https://doi.org/10.1177/2158244015582229

Suyanto, Sapta, I. K. S., \& Sudja, I. N. (2018). The Effect of Career Development and Leadership on Employee Performance with Work Motivation as Intervening Variables on Cv. Blue Waters Bali. International Journal of Contemporary Research and Review, 9(3), 20583-20591 https://doi.org/10.15520/ijcrr/2018/9/03/467

Swanson, R. A. (1995). Human resource development: Performance is the key. Human Resource Development Quartely, 6(2), 207-213.

TAK. (Tax Administration of Kosovo) (2018). Management Reports (Albanian).

Toft-Kehler, R., Wennberg, K., \& Kim, P. H. (2014). Practice makes perfect:Entrepreneurial-experience curves and venture performance. Journal of Business Venturing, 29(4), 453-470. https://doi.org/10.1016/j.jbusvent.2013.07.001

Torraco, R. J. (2005). Work Design Theory: A Review and Critique with Implications for Human Resource 
Development. Human Resource Development Quarterly, 16(1), 85-109. https://doi.org/10.1002/hrdq.1125

Torraco, R. J., \& Swanson, R. A. (1995). The strategia roles of human resource development. Humane Resource Planning, 18(4), 10-21.

Wright, P. M., Gardner, T. M., \& Moynihan, L. M. (2003). The impact of HR practices on the performance of business units.Human Resource. Management Journal, 13(3), 21-36.

\section{Copyrights}

Copyright for this article is retained by the author(s), with first publication rights granted to the journal.

This is an open-access article distributed under the terms and conditions of the Creative Commons Attribution license (http://creativecommons.org/licenses/by/4.0/). 